\title{
Calcium metabolism in pregnant ewes
}

\author{
By G. D. BRAITHWAITE, R. F. GLASCOCK AND SH. RIAZUDDIN \\ National Institute for Research in Dairying, Shinfield, Reading, $R G{ }_{2} A T$
}

(Received 8 October 1969-Accepted 2 February 1970)

\begin{abstract}
I. A combination of balance and isotope techniques has been used to study calcium metabolism in ten sheep at different stages of pregnancy, and the results have been combined with earlier results obtained during lactation to show the variations in Ca metabolism which occur during the whole reproductive cycle.

2. Transfer of $\mathrm{Ca}$ to the foetuses during pregnancy and to the milk after parturition rose rapidly from the $65^{\text {th }}$ day of gestation and reached a maximum at parturition or shortly afterwards.

3. Although the rate of absorption of $\mathrm{Ca}$ from the intestine increased steadily throughout pregnancy it was insufficient to meet the full requirements of late pregnancy and early lactation. During this period, the extra Ca was supplied by increased bone resorption.

4. The maternal $\mathrm{Ca}$ balance became negative during pregnancy, the net daily loss of $\mathrm{Ca}$ reaching a maximum in early lactation.

5. In late lactation the maternal $\mathrm{Ca}$ balance became positive enabling the animals to replenish their skeletal stores.

6. There was no marked change in the demands for $\mathrm{Ca}$ at parturition and the connexion between this observation and the pathogenesis of milk fever is discussed.

7. Rates of transfer of $\mathrm{Ca}$ to the foetus during pregnancy are compared with estimated values of other workers.
\end{abstract}

The technique of Aubert \& Milhaud (1960) has been used in this laboratory to study the effect of milk secretion on various aspects of calcium metabolism in the lactating ewe (Braithwaite, Glascock \& Riazuddin, 1969). In the present work an extension of this technique has been used to study the effect of foetal demands on maternal $\mathrm{Ca}$ economy and these results have been used in conjunction with those obtained from lactating ewes (Braithwaite et al. 1969) to show variations in the Ca metabolism of the ewe at different stages of the reproductive cycle.

\section{EXPERIMENTAL}

Animals, housing and diet. Ten 4-year-old pregnant ewes were used. Four of them were Half-breds (Border Leicester $\times$ Cheviot) which had previously been used in similar experiments during lactation (Braithwaite et al. 1969) and six were Clun Forest. A single experiment was performed on each sheep, and experiments were carried out at different stages of pregnancy. The stage of pregnancy was calculated from the time of mating and the number of foetuses present was determined by $\mathrm{X}$-radiography. The animals were placed in metabolism cages designed for the separate collection of urine and faeces at least $r$ month before the start of an experiment and given a diet of hay and concentrates (Table I). Uneaten food was collected daily and the total amount consumed was determined. Animals had free access to distilled water. 
Experimental procedure. Calcium- 45 as ${ }^{45} \mathrm{CaCl}_{2}$ in aqueous solution was bought from the Radiochemical Centre, Amersham. A known activity (about $200 \mu \mathrm{Ci}$ ) was injected into the jugular vein, and samples of blood, urine and faeces were collected for a period of I week as previously described (Braithwaite et al. 1969). During this period, Ca balance measurements were made. Six of the ewes (nos. 2, 3, 4, 6, 7 and 8 ) were then killed and the foetuses and associated tissues and fluids were removed and weighed. The remaining four ewes (nos. 490-493) on which experiments were performed in late pregnancy were allowed to lamb normally. The lambs were killed immediately after birth and the placentas and fluids collected. The mothers were machine-milked twice daily (Morag, Gibb \& Fox, 1967) after the intravenous injection of 5 i.u. of oxytocin (Pitocin; Parke Davis \& Co., Hounslow, Middlesex), and the total milk volumes were recorded for the ist week of lactation.

Table I. Composition and calcium content of the diet given daily

\begin{tabular}{lccr}
\multicolumn{1}{c}{ Ingredient } & $\begin{array}{c}\text { Amount } \\
(\mathrm{g})\end{array}$ & $\begin{array}{c}\text { Ca content } \\
(\mathrm{mg} / \mathrm{g})\end{array}$ & \multicolumn{1}{c}{$\begin{array}{c}\text { Total Ca } \\
(\mathrm{mg})\end{array}$} \\
Hay & 1000 & $3 \cdot 8 \mathrm{I}$ & $3807 \cdot 0$ \\
Barley & 160 & $\mathrm{I} \cdot 0 \mathrm{I}$ & $16 \mathrm{I} \cdot 6$ \\
Flaked maize & 80 & 0.02 & $\mathrm{I} \cdot 6$ \\
Bran & 40 & 0.58 & $23 \cdot 2$ \\
Linseed oil cake & 20 & $3 \cdot 00$ & $60 \cdot 0$ \\
Mineral mixture* & 20 & $196 \cdot 84$ & $3936 \cdot 8$ \\
Vitamin mixture $\dagger$ & $2 \cdot 8$ & $3 \cdot 79$ & $10 \cdot 6$ \\
Total & & & $8000 \cdot 8$
\end{tabular}

* Super Mindif; Boots Pure Drug Co., Nottingham.

+ Drivite; Boots Pure Drug Co., Nottingham. To supply $x 2500$ i.u. vitamin A and 3 roo i.u. cholecalciferol.

Preparation of the samples for analysis. Blood, faeces, urine and milk samples were prepared as previously described (Braithwaite et al. 1969). The foetal and placental tissues were ashed at $600^{\circ}$ and the ash was dissolved in a known volume of $2 \mathrm{~N}-\mathrm{HCl}$. Amniotic fluid was kept for analysis without treatment.

Determination of $\mathrm{Ca}$. Total $\mathrm{Ca}$ in all samples was measured by atomic absorption spectrophotometry, in food, urine, faeces, milk and foetal tissues by the method of Willis (1961) and in serum by the method of Willis (1960).

Measurement of radioactivity. Radioactivity in serum, faeces and urine samples was measured in a Tri-Carb Liquid Scintillation Spectrometer (Packard model 3314) by the method described previously (Braithwaite et al. 1969). Samples ( $\mathrm{I} \mathrm{ml}$ ) of the extract of ashed foetal tissues in $\mathrm{HCl}$ were counted as described for faeces, and samples of amniotic fluid ( $\mathrm{I} \mathrm{ml}$ acidified with 3 drops of $2 \mathrm{~N}-\mathrm{HCl}$ ) were counted as described for urine.

Kinetic analysis. Methods of kinetic analysis have been reviewed by Aubert, Bronner \& Richelle ( $\mathrm{r}_{963}$ ) and an extension of the full method of Aubert \& Milhaud (1960) as applied to the sheep (Braithwaite et al. 1969 ) has been used in the present work.

It has recently been shown that $\mathrm{Ca}$ transfer across the placenta of the ewe is a oneway process (G. D. Braithwaite, R. F. Glascock \& Sh. Riazuddin, in preparation), Ca 
Vol. 24

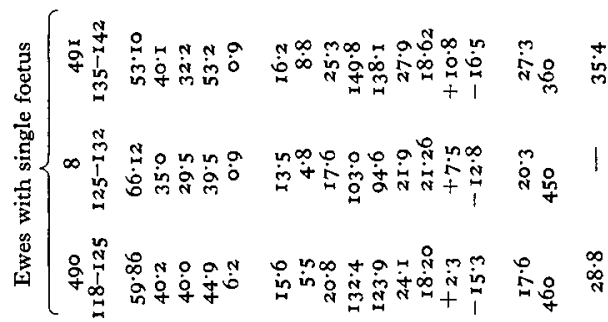

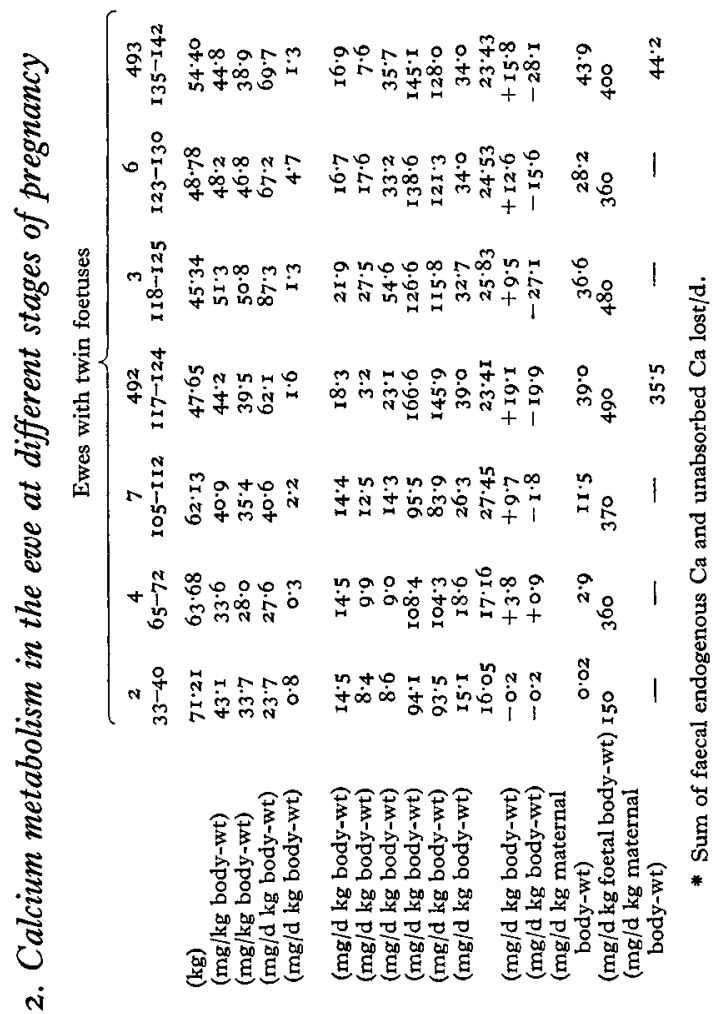

竞

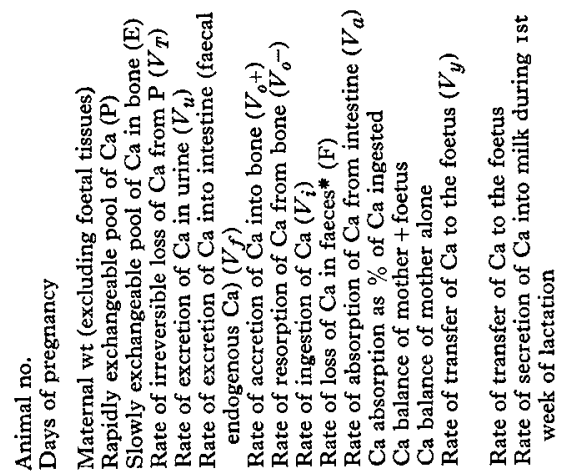


passing only from mother to foetus, and that the foetal $\mathrm{Ca}$ constitutes a separate pool. Furthermore, that work also showed that in the pregnant ewe the equation of Aubert $\&$ Milhaud (1960) for the rate of irreversible loss $\left(V_{T}\right)$ of $\mathrm{Ca}$ from the rapidly exchangeable pool $(\mathrm{P})$ of the mother can be modified to:

$$
V_{T}=V_{u}+V_{f}+V_{\mathrm{o}^{+}}+V_{y},
$$

where $V_{u}$ is the rate of excretion of $\mathrm{Ca}$ in the urine, $V_{f}$ the rate of excretion into the intestine (faecal endogenous $\mathrm{Ca}$ ), $V_{o^{+}}$the rate of accretion of $\mathrm{Ca}$ into bone and $V_{y}$ the rate of transfer of $\mathrm{Ca}$ across the placenta to the foetus. This quantity is calculated in a similar manner to $V_{f}$ from the integral of the specific radioactivity time-curve of serum $\mathrm{Ca}$ and the total radioactivity found in the foetus. Other symbols and terms in the present work are as defined previously (Braithwaite et al. 1969).

\section{RESULTS AND DISCUSSION}

Table 2 shows the values of the various processes of $\mathrm{Ca}$ metabolism at different stages of pregnancy in ewes with single and with twin foetuses. In calculating maternal weights, due allowance has been made for the weight of foetus and associated tissues.

Figs. 1-3 are composite curves plotted from the values in Table 2 and from the

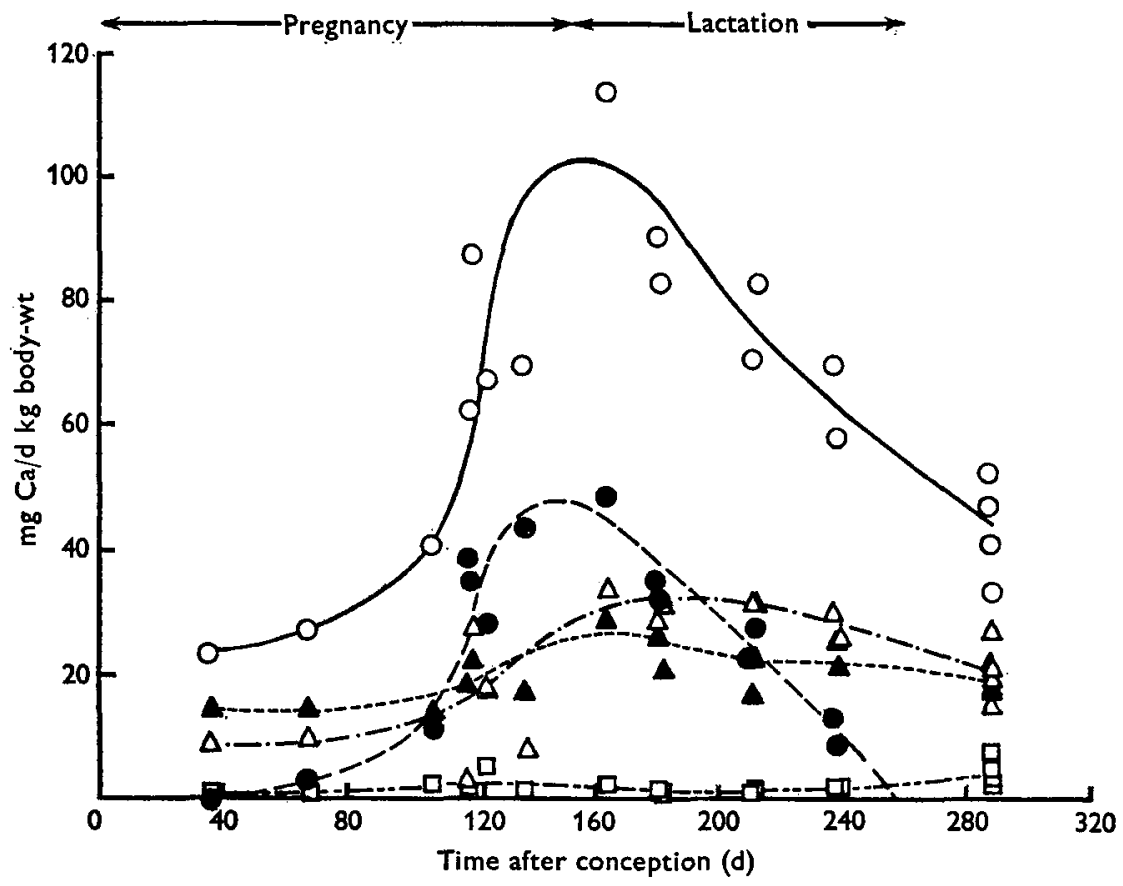

Fig. 1. Variations in the rates of loss of calcium from the rapidly exchangeable pool $P$ of ewes during pregnancy and lactation. Pregnant ewes carried twin foetuses, lactating ewes were machine-milked. $O$, rate of irreversible loss of Ca from $\mathrm{P}$ by all routes $\left(V_{T}\right) ; \square$, rate of excretion of $\mathrm{Ca}$ in urine $\left(V_{u}\right) ; \triangle$, rate of accretion of Ca into bone $\left(V_{o+}\right) ; \boldsymbol{\theta}$, rate of transfer of $\mathrm{Ca}$ to foetuses $\left(V_{y}\right)$ or milk $\left(V_{l}\right) ; \boldsymbol{\Lambda}$, rate of excretion of $\mathrm{Ca}$ into intestine (faecal endogenous $\left.\mathrm{Ca}\right)\left(V_{f}\right)$. 
results of earlier work on the effect of lactation on Ca metabolism (Braithwaite et al. 1969). Although each point thus represents the result from a different animal the curves nevertheless show the variations in the more important processes over the whole reproductive cycle from conception to the end of lactation.

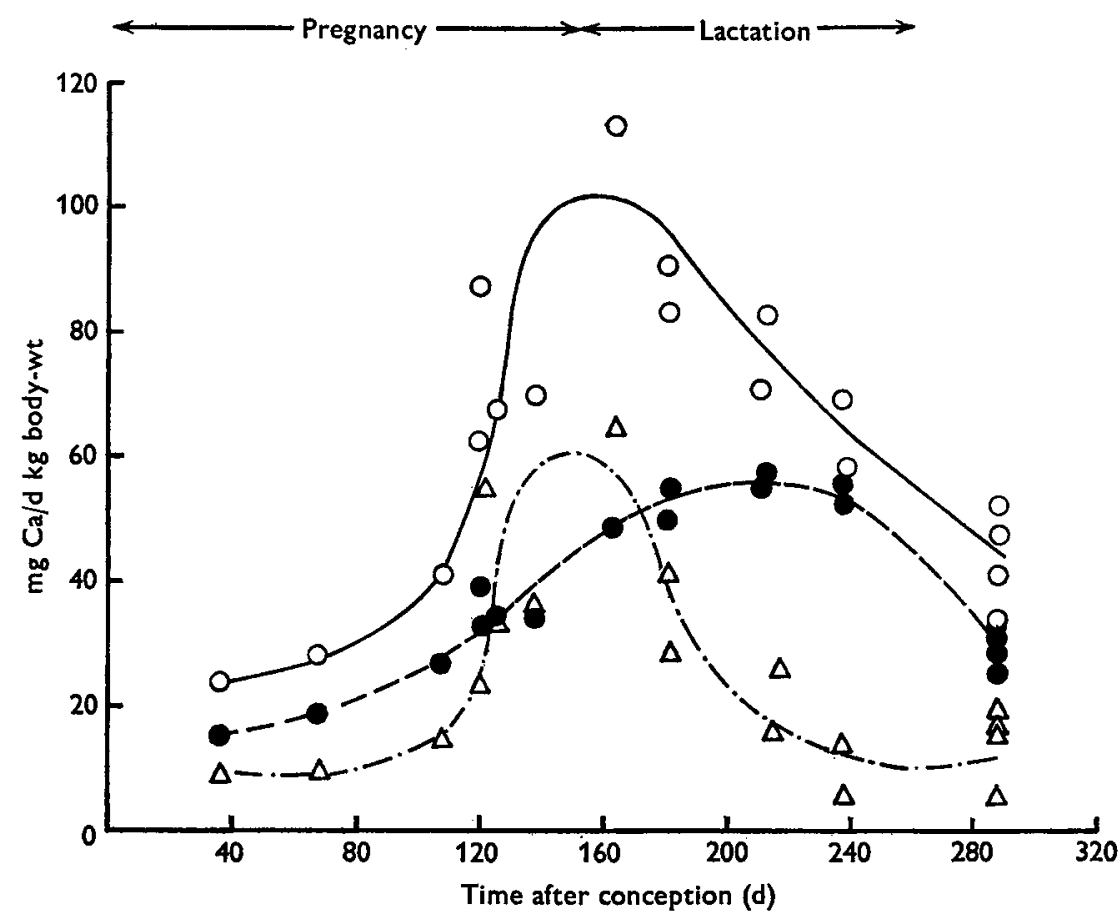

Fig. 2. Variations in the rates of entry of calcium into and loss of calcium from the rapidly exchangeable pool $P$ of pregnant and lactating ewes. $O$, rate of irreversible loss of Ca from $P$ by all routes $\left(V_{T}\right) ; \triangle$, rate of resorption of Ca from bone $\left(V_{o^{-}}\right) ; \boldsymbol{\theta}$, rate of absorption of $\mathrm{Ca}$ from intestine $\left(V_{a}\right)$.

Fig. I shows variations in the rate of loss $\left(V_{T}\right)$ of $\mathrm{Ca}$ from the rapidly exchangeable pool $\mathrm{P}$ of ewes with twin foetuses and of rates of transfer through the four pathways by which this loss occurred, i.e. excretion in the urine, faecal endogenous excretion, accretion into bone and incorporation into the foetuses or into milk. Fig. 2 shows variations in the rates of the two processes, bone resorption and intestinal absorption, which supply $\mathrm{Ca}$ to the pool $\mathrm{P}$, and Fig. 3 shows the Ca balance of the ewes with twin lambs at different stages of pregnancy and lactation.

The rate of transfer of $\mathrm{Ca}$ from the maternal pool $(\mathrm{P})$ to the foetus remained at a low level for the first $65 \mathrm{~d}$ of gestation, but then steadily increased to reach a maximum in late pregnancy (Fig. 1). Although results for early pregnancy were not obtained on ewes with single foetuses, results from i $8 \mathrm{~d}$ onwards showed a similar trend (Table 2 ). Indeed if, as seems reasonable, transfer of $\mathrm{Ca}$ to the foetus and to the milk, after parturition, is treated as a single process, then its rate in ewes with twin foetuses reached a maximum at parturition or shortly afterwards (Fig. I). It has to be noted, however, that if the rate of transfer of $\mathrm{Ca}$ to the foetus was calculated to unit weight of 


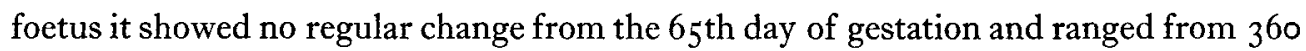
to $490 \mathrm{mg} / \mathrm{d}$ per $\mathrm{kg}$ whether single or twin foetuses were present (Table 2). This suggests that the rate of transfer of $\mathrm{Ca}$ across the placenta was related to the needs of the foetus or foetuses.

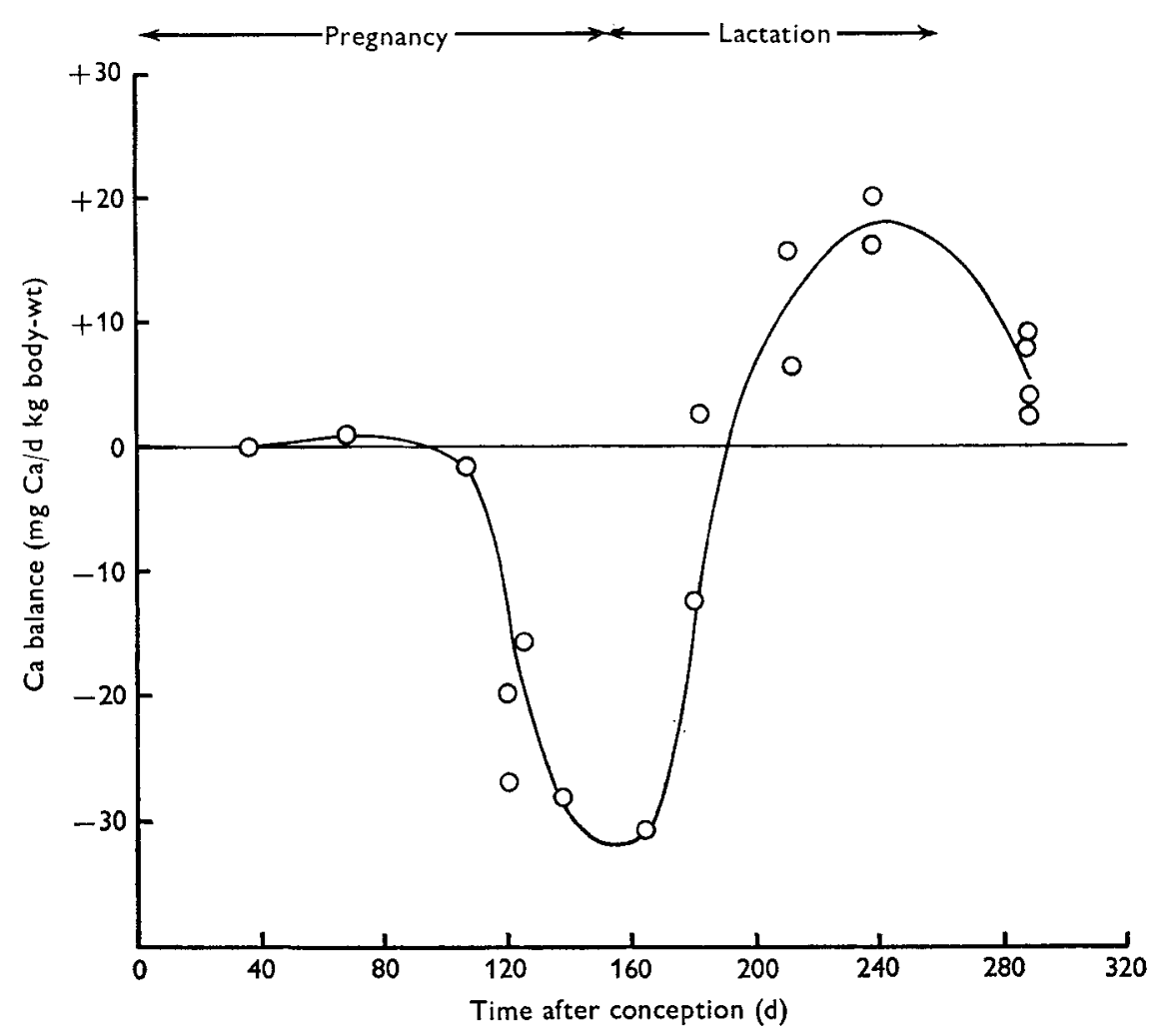

Fig. 3. Calcium balance of ewes with twin lambs at different stages of pregnancy and lactation.

As previously noted (Braithwaite et al. 1969), the rates of both bone accretion $\left(V_{o^{+}}\right)$ and faecal endogenous excretion $\left(V_{f}\right)$ are considerably higher in lactating than in nonlactating animals. The present work shows that the rates of these processes were also much higher in lactation than in mid-pregnancy. Results for late pregnancy, however, showed considerable variation (especially the bone accretion rates) and it was therefore not possible to decide whether they increased during this period. Although the rate of excretion of $\mathrm{Ca}$ in the urine $\left(V_{u}\right)$ varied considerably during pregnancy, the quantities involved were too small to affect $\mathrm{Ca}$ economy appreciably. The sizes of the rapidly exchangeable pool (P) and slowly exchangeable skeletal pool (E) varied considerably from animal to animal (Table 2). There was no evidence, however, of a consistent effect attributable either to pregnancy or to the number of foetuses present.

The increased rate of loss of $\mathrm{Ca}$ to bone, faeces and foetuses or milk is of course reflected in the quantity $V_{T}$ (the rate of loss of $\mathrm{Ca}$ from the pool $\mathrm{P}$ ) which reached a maximum at parturition or shortly afterwards. Fig. 2 shows that the rate of bone 
resorption $\left(V_{o^{-}}\right)$increased more than the rate of absorption from the intestine $\left(V_{a}\right)$ during pregnancy. The rate of bone resorption did not begin to increase appreciably before the 65th day of gestation, for up to this time (Fig. I) the rate of transfer to the foetus was very low. The rate of bone resorption then increased rapidly in late pregnancy and reached a maximum at parturition. Although the rate of absorption from the intestine increased steadily throughout pregnancy, it is evident from Fig. 2 that demands for extra $\mathrm{Ca}$ during this period were met chiefly by bone resorption. After about the 25th day of lactation, however, most of the Ca leaving the pool $\mathrm{P}$ was supplied by $\mathrm{Ca}$ absorbed from the intestine. The rate of entry of this $\mathrm{Ca}$ into the pool then continued at a high level, which was three to four times as great as at conception, until after the end of lactation. As expected, foetal demand for $\mathrm{Ca}$ was lower in ewes with single foetuses than in ewes with twins and was accompanied by lower rates of intestinal absorption and of bone resorption $\left(V_{a}\right.$ and $V_{o^{-}}$, Table 2).

Changes in the value of these various quantities were reflected in the $\mathrm{Ca}$ balance of the animals. There was little net gain of $\mathrm{Ca}$ by the ewe plus foetus at the $35^{\text {th }}$ day of gestation. In later stages of pregnancy, the net daily retention of $\mathrm{Ca}$ by ewe plus foetus increased because of the increased rate of absorption from the intestine (Table 2). The Ca balance of the mother alone became negative at this time (Fig. 3), the net daily loss of $\mathrm{Ca}$ increasing as the quantity $V_{T}$ increased. This was due mainly to transfer of $\mathrm{Ca}$ across the placenta which the slowly increasing rate of absorption from the intestine failed to replace. Although the proportion of dietary Ca absorbed increased from $\mathrm{I} 6$ to $23 \%$ between the 33 rd and 142 nd days of pregnancy, the higher figure does not necessarily represent the limit of availability of dietary $\mathrm{Ca}$. It is far more likely that in pregnancy, as in lactation (Braithwaite et al. 1969), the limiting factor is not the intake of dietary $\mathrm{Ca}$ but the capacity of the intestine to absorb it. The maternal $\mathrm{Ca}$ balance remained negative until about $40 \mathrm{~d}$ after parturition. At this time the rate of bone resorption $\left(V_{o^{-}}\right)$was decreasing rapidly (Fig. 2) and the rates of bone accretion $\left(V_{o^{+}}\right.$, Fig. I) and of absorption of $\mathrm{Ca}$ from the intestine $\left(V_{a}\right.$, Fig. 2) were respectively three and four times as high as at conception. The $\mathrm{Ca}$ balance of the ewes thus became positive and continued to increase in size as losses of $\mathrm{Ca}$ to milk further decreased.

Pregnancy anabolism with respect to several elements, including $\mathrm{Ca}$, occurs in most mammals (Simkiss, 1967). For example, in women (Hummel, Sternberger, Hunscher \& Macy, 1936) and in mice (Spray, 1950) the maternal body contains approximately 4 and $20 \%$ more $\mathrm{Ca}$ immediately after delivery than before conception. It appears from the present work that this phenomenon does not occur in the sheep. Indeed, although the curves shown in Fig. 3 must be only approximate for reasons already stated, graphical integration shows that the mothers lost about I I $\mathrm{g}$, or $20 \%$, of total skeletal $\mathrm{Ca}$ during pregnancy and early lactation. The graph also shows that most of it had been replaced a month after the end of lactation. Similar changes in $\mathrm{Ca}$ balance have also been observed in the rat after periods of deprivation of $\mathrm{Ca}$ (Nicolaysen, Eeg-Larsen \& Malm, 1953). Losses from the skeleton resulted in an increased efficiency of absorption of $\mathrm{Ca}$ which continued until the deficit had been made good. It is possible that the increase in the rate of absorption after periods of negative $\mathrm{Ca}$ balance may result from an increase in the active transport of $\mathrm{Ca}$ across the 
intestinal mucosa. Such an increase has recently been demonstrated in vitro both in pregnant rats (Schachter, Dowdle $\&$ Schenker, 1960 ) and in rats maintained on a low$\mathrm{Ca}$ diet (Kimberg, Schachter \& Schenker, 1961). Although parathyroid hormone cannot be excluded (Kimberg et al. I96I; Shah \& Draper, I966), the identity of the factor controlling $\mathrm{Ca}$ absorption is unknown. Nicolaysen (1943) suggested that it might be derived from the cellular elements of demineralized bone, but numerous experiments on rat bones have failed to extract such an active material (Nicolaysen, I96r).

\section{Pathogenesis of milk fever}

Symonds, Manston, Payne \& Sansom (1966) found that in the cow there is a much increased demand for $\mathrm{Ca}$ at parturition. Thus, whereas in one animal studied the rate of transfer of $\mathrm{Ca}$ to the foetus just before birth was $5.3 \mathrm{~g} / \mathrm{d}$, the average daily rate of loss of $\mathrm{Ca}$ in the milk during the Ist week of lactation was $13.7 \mathrm{~g}$. They suggested that such sudden increases in loss of maternal Ca might be the cause of milk fever. In the ewe, on the other hand, Field \& Suttle (1967) found that there was little change in the demand for $\mathrm{Ca}$ at parturition, and this would be consistent with the fact that the ewe is not susceptible to milk fever. The results of the present work are in general agreement in this respect with those of Field \& Suttle. Two of the sheep which had single lambs (nos. 490, 49I) and two which had twins (nos. 492, 493) were studied further during the ist week of lactation. In the mothers of twins the rate of secretion of $\mathrm{Ca}$ into the milk per unit maternal body-weight was about the same as the rate of transfer to the foetus during late pregnancy (Table 2). In the mothers of single lambs the rates of secretion into milk were $I \cdot 64$ and $I \cdot 3$ times as great as the rate of transfer to the foetus. It must be remembered, however, that these animals were milked by machine, which would tend to maintain the rate of secretion in the mothers of single lambs at a higher level than would occur if the lambs were suckling. Wallace (I948) observed that ewes nursing twins produced $\mathrm{r} \cdot 6$ times as much milk as ewes with single lambs. At parturition, therefore, there would be no marked change in the demand on maternal $\mathrm{Ca}$ reserves in ewes who rear their own lambs.

\section{Comparison with other work}

The results obtained in the present work on the rate of transfer of $\mathrm{Ca}$ to the foetus may be compared with those calculated from values published by other workers. Field $\&$ Suttle (1967) measured the mineral content and weight of foetuses at different ages and calculated the corresponding rates of deposition of $\mathrm{Ca}$ in the foetus. These rates were also estimated by the authors of The Nutrient Requirements of Farm Livestock (Agricultural Research Council, I965). From both these sets of data, the rate of accretion of Ca per unit foetal weight may be calculated, and these values together with the total rate of deposition of $\mathrm{Ca}$ are shown for the purposes of comparison in Table 3 .

The daily rates of deposition into single foetuses measured in the present work are in good agreement with those of Field \& Suttle, but the rates for twins are appreciably lower. It must be noted, however, that these workers considered that the weights of 


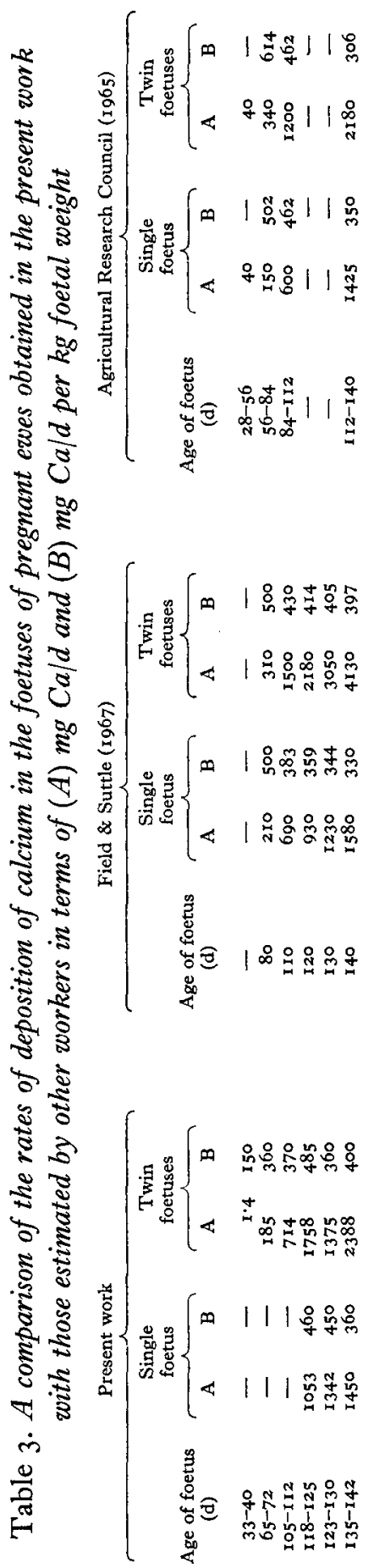


twin foetuses may have been from an unrepresentative sample of animals and were consequently higher than average. When rates of deposition per unit foetal weight are compared, the discrepancy for twins disappears. The values obtained both in the present work and in that of Field \& Suttle appear fairly constant in the later stages of pregnancy, irrespective of the number of foetuses present. Values calculated from the results given in The Nutrient Requirements of Farm Livestock, however, are rather high up to mid-pregnancy, and they then progressively diminish. These changing values are possibly due to the assumptions on which these authors based their calculations. It would seem, therefore, that the results of the present work which were obtained by a more direct method of measurement are more reliable than those of earlier workers.

We wish to thank Mr G. Lovering for technical assistance and $\mathrm{Mr} \mathrm{R}$. Ellis and Mr A. Wilim for the care and feeding of the ewes. One of us (Sh. R., a visiting worker from the Pakistan Atomic Energy Commission, Lahore) is the holder of a Colombo Plan Fellowship.

\section{REFEREN CES}

Agricultural Research Council (1965). The Nutrient Requirements of Farm Livestock. No. 2. Ruminants. London: HM Stationery Office.

Aubert, J.-P., Bronner, F. \& Richelle, L. J. (1963). F. clin. Invest. 42, 885.

Aubert, J.-P. \& Milhaud, G. (1960). Biochim. biophys. Acta 39, 122.

Braithwaite, G. D., Glascock, R. F. \& Riazuddin, Sh. (1969). Br. J. Nutr. 23, 827.

Field, A. C. \& Suttle, N. F. (1967). Y. agric. Sci., Camb. 69, 417.

Hummel, F. C., Sternberger, H. R., Hunscher, H. A. \& Macy, I. G. (r936). F. Nutr. I1, 235.

Kimberg, D. V., Schachter, D. \& Schenker, H. (1961). Am. F. Physiol. 200, 1256.

Malm, O. J. (1963). In The Transfer of Calcium and Strontium across Biological Membranes [R. H. Wasserman, editor]. New York and London: Academic Press.

Morag, M., Gibb, J. A. C. \& Fox, S. (1967). F. Dairy Res. 34, 215.

Nicolaysen, R. (1943). Acta physiol. scand. 5, 200.

Nicolaysen, R. (I96I). Ernährungsforschung Suppl. no. 1, p. 71. Quoted by Malm (1963).

Nicolaysen, R., Eeg-Larsen, N. \& Malm, O. J. (1953). Physiol. Rev. 33, 424.

Schachter, D., Dowdle, E. B. \& Schenker, H. (1960). Am. F. Physiol. 198, 263.

Shah, B. G. \& Draper, H. H. (1966). Am. F. Physiol. 2r1, 963.

Simkiss, K. (1967). Calcium in Reproductive Physiology. London: Chapman \& Hall Ltd, New York: Reinhold Publishing Corporation.

Spray, C. M. (I950). Br. F. Nutr. 4, 354 .

Symonds, H. W., Manston, R., Payne, J. M. \& Sansom, B. F. (1966). Br. vet. F. 122, 196.

Wallace, L. R. (1948). 7. agric. Sci., Camb. 38, 93 .

Willis, J. B. (1960). Spectrochim. Acta r6, 259.

Willis, J. B. (г96r). Analyt. Chem. 33, 556. 